\title{
Synthesis and antimicrobial activity of metal complexes from 2-(1'/2'-hydroxynaphthyl)benzoxazoles
}

\author{
Anil Kumar and Devinder Kumar* \\ Department of Chemistry, Guru Jambheshwar University of Science and Technology, Hisar- \\ 125001, Haryana, India \\ E-mail: $\underline{\text { dkic@yahoo.com }}$
}

\begin{abstract}
Synthesis and antimicrobial activity of new metal [Mg(II), Fe(II), Co(II), Ni(II), Zn(II) and $\mathrm{Cd}(\mathrm{II})$ ] complexes from 2-(1'/2'-hydroxynaphthyl)benzoxazoles have been described. Some of the metal complexes show significant antifungal activity (MIC $<3.12 \mu \mathrm{g} / \mathrm{ml})$. Further, 2-(1'/2'hydroxynaphthyl)benzoxazoles exhibit excited-state intramolecular proton transfer mechanism that has been studied using absorbance and fluorescence spectroscopy.
\end{abstract}

Keywords: Benzoxazoles, 2-(1'/2'-hydroxynaphthyl)benzoxazoles, metal complexes, antimicrobial activity

\section{Introduction}

The excited-state intramolecular proton transfer (ESIPT) of 2-(2'-hydroxyphenyl)benzoxazoles (HBOs) has been studied under physiological conditions using absorbance and steady-state emission spectroscopy and inhibition of ESIPT via metal coordination showed a significant wavelength shift ${ }^{1}$. HBOs exhibit fluorescent and luminescent properties ${ }^{2}$ and good thermal and photo stabilities ${ }^{3}$ and are excellent materials for plastic scintillation applications ${ }^{4}$ and some of their metal complexes are of interest for the organic light emitting diode (OLED) technology ${ }^{5}$. It has also been proposed that HBO behave as structural mimic of DNA base pair for which tautomerism may be initiated at a defined time and position within duplex DNA ${ }^{6}$. HBO moiety is also present in a number of synthetic metal ion chelators ${ }^{7}$. A natural product bis(benzoxazole) (UK-1) also having this moiety has been reported to possess anticancer activity and the metal ion binding studies of UK-1 indicates that it is capable of binding a variety of biologically important metal ions $^{8}$. Recently, we have also demonstrated the metal-mediated DNA binding of UK-1 by ESI-MS that it forms complexes with a variety of metal ions ${ }^{9}$. The numerous applications of HBO promoted to undertake the synthesis of $2-\left(1^{\prime} / 2^{\prime}\right.$-hydroxynaphthyl)benzoxazoles by replacing the 2'-hydroxyphenyl moiety in HBO with 1'/2'-hydroxynaphthyl moiety and to study 
the effect of metal ion binding as well as for evaluation of in vitro antimicrobial activity of metal complexes.

\section{Results and Discussion}

The reaction of 2-aminophenol (1) with 1-hydroxynaphthaldehyde (2) in presence of iodobenzene diacetate (IBD) resulted in 2-(1'-hydroxynaphthyl)benzoxazole (4) via the intermediacy of 3 (Scheme 1) in one pot and in $70 \%$ yield which was purified by column chromatography. All the physical and spectroscopic (UV, IR, NMR) data were in consonance with the structure.

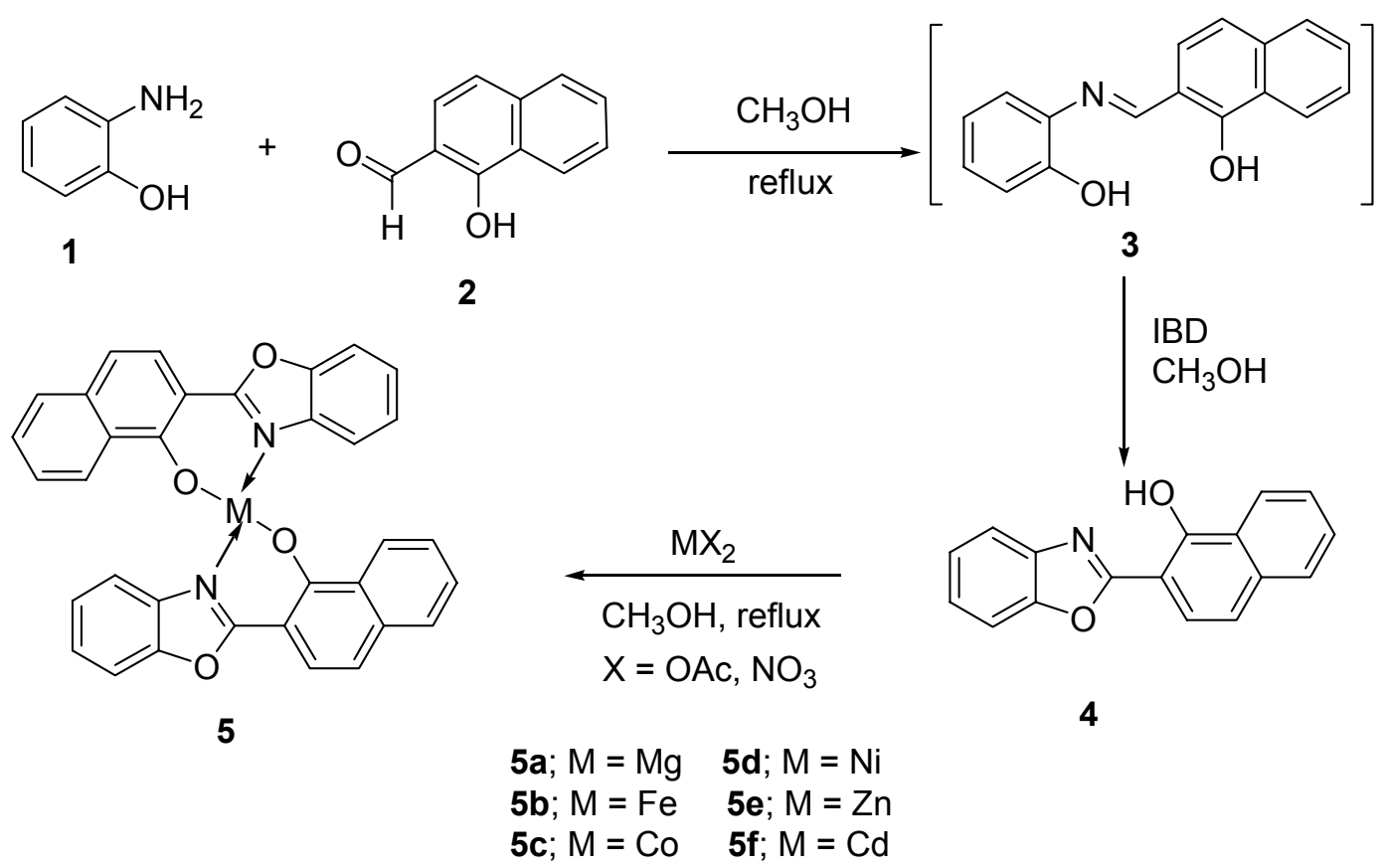

\section{Scheme 1}

2-(1'-Hydroxynaphthyl)benzoxazoles (4) exhibit excited-state intramolecular proton transfer (ESIPT) process similar to 2-(2'-hydroxyphenyl)benzoxazole which has widespread implications (Scheme 2). The absorption and fluorescence peaks of 4 are at 365 and $468 \mathrm{~nm}$, respectively. The large difference in absorption and emission spectra is expected due to an excited-state intramolecular proton transfer. The ESIPT process is very fast and occurs in excited-state enol tautomer that undergoes an intramolecular proton transfer reaction with the neighboring hydrogen-bonded nitrogen atom giving rise to the excited keto tautomer which then emits a strongly Strokes-shifted fluorescence. 


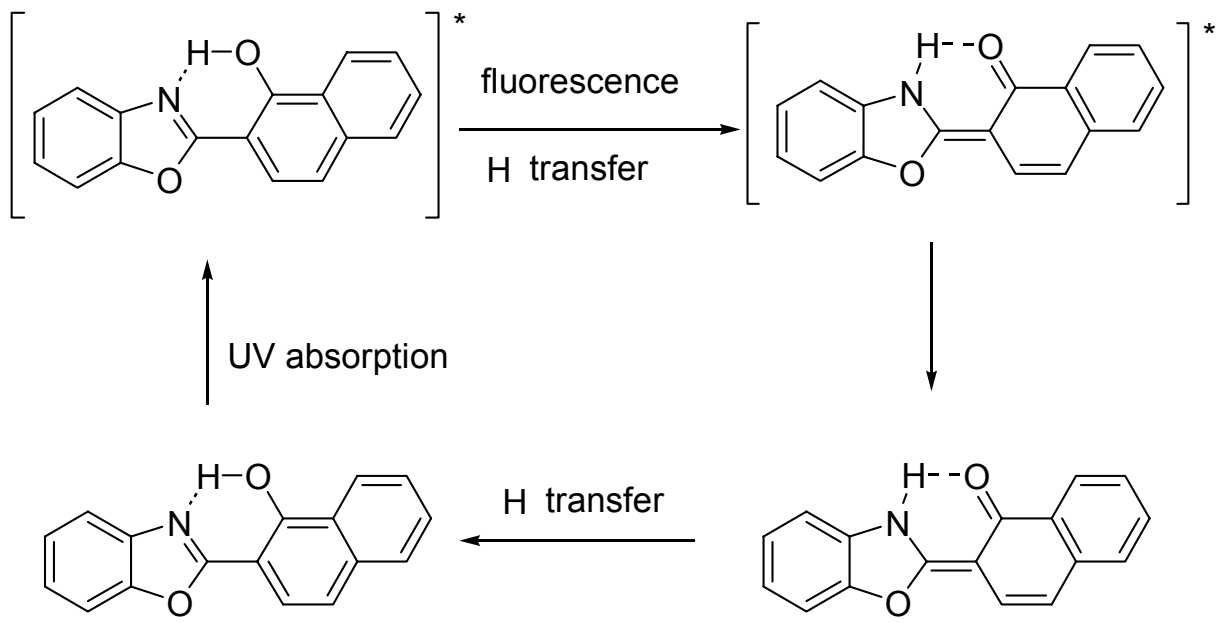

\section{Scheme 2}

Further, the reaction of 2-aminophenol (1) with 2-hydroxynaphthaldehyde in presence of IBD afforded 2-(2'-hydroxynaphthyl)benzoxazole (6) which was purified by column chromatography. All the physical and spectroscopic (UV, IR, NMR) data were in consonance with the structure. The absorption and fluorescence peaks of 6 are at 373 and $443 \mathrm{~nm}$, respectively. The large difference in absorption and emission spectra is again expected due to an excited-state intramolecular proton transfer.

In an alternate method, 4 and $\mathbf{6}$ were also obtained by one step reaction of $\mathbf{1}$ and 1hydroxynaphthoic acid and 2-hydroxynaphthoic acid, respectively in presence of polyphosphoric acid in good yields.

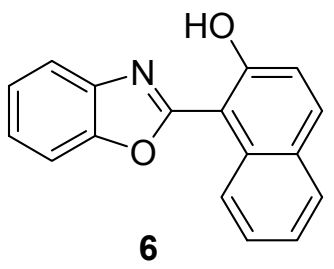

$$
\begin{aligned}
& \mathrm{MX}_{2} \\
& \mathrm{CH}_{3} \mathrm{OH} \text {, reflux } \\
& \mathrm{X}=\mathrm{OAc}, \mathrm{NO}_{3} \\
& \text { 7a; } M=M g \quad 7 d ; M=N i \\
& \text { 7b; } M=\mathrm{Fe} \quad 7 \mathrm{e} ; M=\mathrm{Zn} \\
& \text { 7c; } M=C o \text { 7f; } M=C d
\end{aligned}
$$

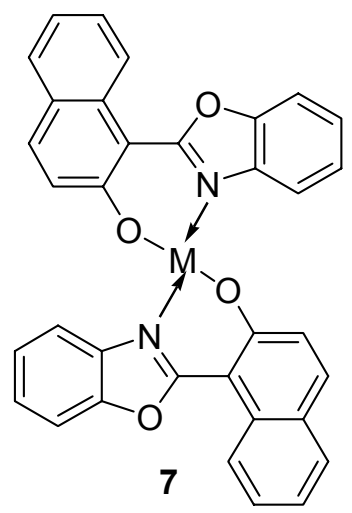

\section{Scheme 3}

Furthermore, we examined the reactions of 4 and $\mathbf{6}$ with metal $[\mathrm{Mg}(\mathrm{II}), \mathrm{Fe}(\mathrm{II}), \mathrm{Co}(\mathrm{II}), \mathrm{Ni}(\mathrm{II})$, $\mathrm{Zn}(\mathrm{II})$ and $\mathrm{Cd}(\mathrm{II})]$ salts in 1:2 ratio that generated new metal complexes 5 and 7, respectively 
(Schemes 1 and 2). The structures of new metal complexes were established through elemental analysis, UV, IR and mass spectral studies. The absorption and fluorescence values of metal complexes (5 and 7) indicate the influence of metal cation binding on the proton transfer process (Table 1). The chelation of metal cations competes with protonation of the ligand donor atoms. The proton transfer is disrupted by coordination of the metal ion, but the red-shift tautomer emission did not disappear in favour of normal emission, instead, the complexation led to a change in both the absorption and emission spectra (Table 1).

The IR spectra of $\mathbf{5}$ and $\mathbf{7}$ are also in complete agreement with their structures. There was sharp modification between the IR spectra of the metal complexes and the ligands. Most of the bands changed their pattern in the region probably due to coordination of the oxygen atom of $\mathrm{OH}$ group and nitrogen atom of the ligand to metal ions (vide experimental). The matrix-assisted laser desorption ionization (MALDI) mass spectra supported the structures of the metal complexes.

Table 1. The UV and fluorescence emission data of ligand and metal complexes

\begin{tabular}{cccccccc}
\hline $\begin{array}{c}\text { Ligand/ } \\
\text { Complexes }\end{array}$ & Metal & $\begin{array}{c}\lambda_{\text {max }}^{\text {abs }} \\
(\mathrm{nm})\end{array}$ & $\begin{array}{c}\lambda_{\text {max }}^{\text {flu }} \\
(\mathrm{nm})\end{array}$ & Compound & Metal & $\begin{array}{c}\lambda^{\text {abs }} \\
(\mathrm{nm})\end{array}$ & $\begin{array}{c}\lambda_{\max }^{\text {flu }} \\
(\mathrm{nm})\end{array}$ \\
\hline 4 & - & 365 & 468 & 6 & - & 373 & 443 \\
$5 \mathrm{a}$ & $\mathrm{Mg}$ & 321 & 465 & $7 \mathrm{a}$ & $\mathrm{Mg}$ & 373 & 463 \\
$5 \mathrm{~b}$ & $\mathrm{Fe}$ & 366 & - & $7 \mathrm{~b}$ & $\mathrm{Fe}$ & 356 & - \\
$5 \mathrm{c}$ & $\mathrm{Co}$ & 392 & - & $7 \mathrm{c}$ & $\mathrm{Co}$ & 357 & - \\
$5 \mathrm{~d}$ & $\mathrm{Ni}$ & 415 & 463 & $7 \mathrm{~d}$ & $\mathrm{Ni}$ & 373 & 468 \\
$5 \mathrm{e}$ & $\mathrm{Zn}$ & 366 & 568 & $7 \mathrm{e}$ & $\mathrm{Zn}$ & 403 & 492 \\
$5 \mathrm{f}$ & $\mathrm{Cd}$ & 350 & 502 & $7 \mathrm{f}$ & $\mathrm{Cd}$ & 400 & 470 \\
\hline
\end{tabular}

The complexation of biologically important metals with 2-(1'/2'hydroxynaphthyl)benzoxazoles was further explored with the evaluation of their antimicrobial activity. The new ligands (4 and 6) and their metal complexes (5 and 7) were evaluated for in vitro antibacterial activity against Gram-positive Bacillus subtilis [MTCC 2063], Staphylococcus aureus [MTCC 2901] and Gram-negative Escherichia coli [MTCC 1652] and in vitro antifungal activity against Aspergillus ficuum [MTCC 8184], Aspergillus parasiticus [MTCC 8189], Candida albicans [MTCC 183] and Aspergillus niger [MTCC 1344]. Double strength nutrient broth-I.P. and Sabouraud dextrose broth-I.P. ${ }^{10}$ were employed for bacterial and fungal growth, respectively. Minimum Inhibitory Concentrations (MIC) were determined by means of standard serial dilution method ${ }^{11}$ and are presented in Table 2. All the ligands/complexes exhibited appreciable in vitro activity against the tested strains. 
Table 2. The in vitro antimicrobial activity of metal complexes (MIC in $\mu \mathrm{g} / \mathrm{ml}$ )

\begin{tabular}{cccccccc}
\hline \multirow{2}{*}{ Compd } & \multicolumn{3}{c}{ Antibacterial activity } & \multicolumn{4}{c}{ Antifungal activity } \\
& B. subtilis & E. coli & S. aureus & A. ficuum & A. parasiticus & C. albicans & A. niger \\
\hline $\mathbf{4}$ & $>50$ & 12.5 & 25 & 6.25 & 12.5 & 12.5 & 12.5 \\
$\mathbf{5 a}$ & $>50$ & 25 & 50 & 6.25 & 12.5 & $<3.12$ & 12.5 \\
$\mathbf{5 b}$ & 50 & 50 & 25 & 6.25 & 12.5 & 12.5 & 12.5 \\
$\mathbf{5 c}$ & 12.5 & 25 & 12.5 & 6.25 & 25 & 12.5 & 12.5 \\
$\mathbf{5 d}$ & $>50$ & 25 & 25 & 6.25 & 12.5 & 12.5 & 12.5 \\
$\mathbf{5 e}$ & 12.5 & 50 & 25 & 6.25 & 12.5 & 12.5 & 12.5 \\
$\mathbf{5 f}$ & 25 & 50 & 50 & 6.25 & 12.5 & 12.5 & 6.25 \\
$\mathbf{6}$ & 50 & 50 & 50 & 6.25 & 6.25 & 12.5 & 12.5 \\
$\mathbf{7 a}$ & $>50$ & 25 & 50 & 6.25 & 25 & 12.5 & 12.5 \\
$\mathbf{7 b}$ & $>50$ & $>50$ & 25 & 6.25 & 6.25 & 12.5 & 12.5 \\
$\mathbf{7 c}$ & 25 & 6.25 & 25 & 6.25 & 6.25 & 12.5 & 12.5 \\
$\mathbf{7 d}$ & 50 & 6.25 & $>50$ & 3.12 & 6.25 & 12.5 & 12.5 \\
$\mathbf{7 e}$ & 25 & 6.25 & 25 & 6.25 & 6.25 & 12.5 & 12.5 \\
$\mathbf{7 f}$ & 25 & 50 & 25 & 6.25 & 6.25 & 6.25 & 12.5 \\
\hline
\end{tabular}

\# The MIC of standard drugs for antibacterial activity (Tetracycline, Chloramphenicol, Kanamycin, Cefazoline sodium and Cefotaxime) and antifungal activity (Cycloheximide, Carbendazim and Fluconazole) were found to be $<3.12 \mu \mathrm{g} / \mathrm{ml}$.

Table 2 indicates that metal complex 5c, 5e and 7c-7e showed good antibacterial activity against Bacillus subtilis and Escherichia coli, respectively. The metal complex 5c also displayed good antibacterial activity against Staphylococcus aureus. Further, the antifungal activity of metal complex 7d was found to be significant against Aspergillus ficuum, while the ligand $\mathbf{6}$ and its metal complexes $\mathbf{7 b - 7 f}$ showed similar antifungal activity against Aspergillus parasiticus. Further, the antifungal activity of metal complex 5a was found to be significant against Candida albicans among others. Finally, the metal complex 5f was the only one to display better antifungal activity against Aspergillus niger. Most of the metal complexes showed better activity than their respective ligands (4 and 6). These results indicate that the increase in the size of the transition metal ions from iron to cadmium has no substantial effect on the antimicrobial activity except the nickel complex (7d) that possesses appreciable antifungal activity against Aspergillus ficuum. Interestingly the magnesium complex (5a) was found to exhibit significant antifungal activity against Candida albicans. It was also noticed that all the compounds, ligands and metal complexes were more active as antifungal than as antibacterial.

In conclusion, we have synthesized new ligands and their metal complexes and evaluated their antimicrobial activity. The results clearly showed that the magnesium complex (5a) and the nickel complex (7d) possess significant antifungal activity against Candida albicans and Aspergillus ficuum. Further, it guides us to design and synthesize the analogs of 
bis(benzoxazoles), a natural product by substituting 1/2-hydroxynaphthyl moiety in place of 2hydroxyphenyl moiety and to study their metal mediated binding studies.

\section{Experimental Section}

The melting points were determined in open capillaries and are uncorrected. The UV (methanol) and florescence spectra (solid) were recorded on Cary 5000 and Fluromax G (SPEX) spectrophotometer. The FTIR spectra were obtained in $\mathrm{KBr}$ on Perkin Elmer Spectrum RX1 instruments and are reported in $\mathrm{cm}^{-1}$. ${ }^{1} \mathrm{H}$ and ${ }^{13} \mathrm{C}$ NMR spectra were recorded on Bruker Avance II $400 \mathrm{MHz}$ and $100 \mathrm{MHz} \mathrm{NMR}$ spectrometer, respectively in $\mathrm{CDCl}_{3}$ and are expressed as ppm with respect to TMS. Elemental analysis was carried out on Perkin Elmer 2400 instrument. The mass spectra were recorded on Voyager Elite MALDI-TOF instrument.

Iodobenzene diacetate and metal salts [magnesium(II) nitrate, iron(II) nitrate, cobalt(II) nitrate, nickel(II) nitrate, zinc(II) acetate and cadmium(II) acetate] were purchased from Aldrich and were used without further purification. All the solvents were purified using standard procedures. The new ligands (4 and $\mathbf{6}$ ) have been made utilizing literature procures. ${ }^{12,13}$

\section{2-(1'-Hydroxynaphthyl)benzoxazole (4)}

A mixture of 2-aminophenol $(3.27 \mathrm{~g}, 0.03 \mathrm{mmol})$ and 1-hydroxynaphthaldehyde $(5.16 \mathrm{~g}, 0.03$ mmol) were refluxed in methanol $(40 \mathrm{ml})$ for $2 \mathrm{~h}$. The reaction mixture was cooled to room temperature and IBD $(9.66 \mathrm{~g}, 0.033 \mathrm{mmol})$ was added and stirred for $1 \mathrm{~h}$. The solvent was distilled off and the residue was purified by column chromatography using hexane to afford $\mathbf{4}$, yield 70\%; m.p. $218^{\circ} \mathrm{C}$; UV $\left(\mathrm{CH}_{3} \mathrm{OH}\right) \lambda$ : 365, 349, 321, 308, 285, 270, 261, 243, 221, 203 nm; FTIR (KBr) v: 1635, 1579, 1552, 1498, 1454, 1409, 1331, 1291, 1250, 1147, 1125, 1071, 949, 883, 809, 747, 722, $660 \mathrm{~cm}^{-1} ;{ }^{1} \mathrm{H} \mathrm{NMR}\left(\mathrm{CDCl}_{3}\right) \delta: 12.56($ br s, $1 \mathrm{H}), 8.53(\mathrm{dd}, \mathrm{J}=7.8,1.1 \mathrm{~Hz}$, $1 \mathrm{H}), 8.03(\mathrm{~d}, \mathrm{~J}=8.7 \mathrm{~Hz}, 1 \mathrm{H}), 7.83(\mathrm{dd}, \mathrm{J}=7.2,1.2 \mathrm{~Hz}, 1 \mathrm{H}), 7.78-7.75(\mathrm{~m}, 1 \mathrm{H}), 7.66-7.57$ (m, 3H), $7.46(\mathrm{~d}, \mathrm{~J}=8.7 \mathrm{~Hz}, 1 \mathrm{H}), 7.42-7.39(\mathrm{~m}, 2 \mathrm{H}) ;{ }^{13} \mathrm{C} \mathrm{NMR}\left(\mathrm{CDCl}_{3}\right) \delta: 163.8,157.2,149.2$, 140.2, 136.1, 128.7, 127.7, 125.9, 125.1, 125.0, 124.9, 123.8, 122.3, 119.3, 119.0, 110.7, 103.8; Mass Calcd. for $\mathrm{C}_{17} \mathrm{H}_{11} \mathrm{NO}_{2}$ 261.0789. Found 261.0797 (100); Anal. Calcd. for $\mathrm{C}_{17} \mathrm{H}_{11} \mathrm{NO}_{2}$ : $\mathrm{C}$, 78.15; H, 4.24; N, 5.36\%. Found: C, 78.14; H, 3.95; N, 5.55\%.

Similarly, 2-(2'-hydroxynaphthyl)benzoxazole (6) was obtained in $60 \%$ yield, m.p. $150-152^{\circ} \mathrm{C}$; UV $\left(\mathrm{CH}_{3} \mathrm{OH}\right) \lambda:$ 373, 357, 319, 306, 253, 245, 227, 203 nm; FTIR (KBr) v: 3428, 1617, 1535, 1459, 1420, 1378, 1336, 1289, 1257, 1207, 1181, 1125, 1009, 971, 892, 808, 747, 725, 658; ${ }^{1} \mathrm{H}$ NMR $\left(\mathrm{CDCl}_{3}\right) \delta: 13.35($ br s, $1 \mathrm{H}, \mathrm{OH}), 9.10(\mathrm{dd}, \mathrm{J}=8.7,0.6 \mathrm{~Hz}, 1 \mathrm{H}), 7.89(\mathrm{~d}, \mathrm{~J}=8.96 \mathrm{~Hz}, 1 \mathrm{H})$, 7.82-7.63 (m, 4H), 7.43-7.40 (m, 3H), $7.32(\mathrm{~d}, \mathrm{~J}=8.9 \mathrm{~Hz}, 1 \mathrm{H}) ;{ }^{13} \mathrm{C} \mathrm{NMR}\left(\mathrm{CDCl}_{3}\right) \delta: 164.8$, $161.1,148.9,138.5,134.9,130.9$, 129.2, 128.6, 128.4, 125.3, 125.2, 124.6, 123.8, 119.4, 118.8, 110.8, 102.5; Mass Calcd. for $\mathrm{C}_{17} \mathrm{H}_{11} \mathrm{NO}_{2}$ 261.0789. Found 261.0779 (100); Anal. Calcd. for $\mathrm{C}_{17} \mathrm{H}_{11} \mathrm{NO}_{2}$ : C, 78.15; H, 4.24; N, 5.36\%. Found: C, 78.25; H, 3.91; N, 5.47\%.

In an alternate method ${ }^{13}$ 2-aminophenol $(3.27 \mathrm{~g}, 0.03 \mathrm{mmol})$ and 1-hydroxynaphthoic acid/2hydroxynaphthoic acid $(5.16 \mathrm{~g}, 0.03 \mathrm{mmol})$ were heated in presence of polyphosphoric acid 
$(100 \mathrm{~g})$ at $180^{\circ} \mathrm{C}$ for $6 \mathrm{~h}$ under nitrogen atmosphere. The reaction mixture was cooled to room temperature and poured in water to afford 4 and 6, in 67\% and 69\% yields, respectively which were purified by column chromatography using hexane as eluent.

\section{Metal complexes}

General procedure: To a solution of $4 / 6(261 \mathrm{mg}, 1 \mathrm{mmol})$ in methanol $(15 \mathrm{ml})$ was added a few drops of $10 \%$ aq. sodium hydroxide and a solution of metal salt $(0.5 \mathrm{mmol})$ in methanol $(5$ $\mathrm{ml}$ ). The reaction mixture was refluxed for $24 \mathrm{~h}$ and cooled. The product thus separated was filtered, washed with water and dried to give 5a-5f and 7a-7f.

\section{Metal complexes of 2-(1'-hydroxynaphthyl)benzoxazoles (5a-5f)}

5a; Colourless powder, yield $40 \%$; m.p. $>360^{\circ} \mathrm{C}$; $\mathrm{UV}\left(\mathrm{CH}_{3} \mathrm{OH}\right) \lambda$ : 321, 307, 298, 283, 271, 261, 222 nm; FTIR (KBr) v: 3413, 1610, 1562, 1543, 1497, 1459, 1412, 1384, 1330, 1285, 1250, 1208, 1146, 1077, 1004, 953, 889, 790, $739 \mathrm{~cm}^{-1}$; Anal. Calcd for $\mathrm{C}_{34} \mathrm{H}_{20} \mathrm{MgN}_{2} \mathrm{O}_{4}$ : C, 74.95; $\mathrm{H}$, 3.70; N, 5.14\%. Found: C, 74.77; H, 3.56; N, 5.31\%.

5b; Green powder, yield 47\%; m.p. $>360^{\circ} \mathrm{C}$; UV $\left(\mathrm{CH}_{3} \mathrm{OH}\right) \lambda$ : 366, 349, $286 \mathrm{~nm}$; FTIR (KBr) v: 3411,1602 , 1561, 1533, 1490, 1455, 1411, 1383, 1309, 1256, 1228, 1149, 1085, 1004, 979, 889, 809, 757, $741 \mathrm{~cm}^{-1}$; Anal. Calcd for $\mathrm{C}_{34} \mathrm{H}_{20} \mathrm{FeN}_{2} \mathrm{O}_{4}$ : C, 70.85; H, 3.50; N, 4.86\%. Found: C, $70.67 ; \mathrm{H}, 3.27$; N, $4.83 \%$.

5c; Light brown powder, yield $39 \%$; m.p. $>360^{\circ} \mathrm{C}$; $\mathrm{UV}\left(\mathrm{CH}_{3} \mathrm{OH}\right) \lambda$ : 392, 367, 350, 299, 287 , 225 nm; FTIR (KBr) v: 1607, 1557, 1534, 1487, 1458, 1449, 1420, 1384, 1333, 1301, 1255 , 1191, 1147, 1087, 1001, 977, 906, 887, 873, 791, 755, $736 \mathrm{~cm}^{-1}$; Anal. Calcd for $\mathrm{C}_{34} \mathrm{H}_{20} \mathrm{CoN}_{2} \mathrm{O}_{4}$ : C, 70.47; H, 3.48; N, 4.83\%. Found: C, 70.36; H, 3.26; N, 5.14\%.

5d; Light brown powder, yield $40 \%$; m.p. $>360^{\circ} \mathrm{C}$; $\mathrm{UV}\left(\mathrm{CH}_{3} \mathrm{OH}\right) \lambda$ : 415, 393, 366, 349, 321, 300, 285, 270, 265, 225 nm; FTIR (KBr) v: 3435, 1636, 1609, 1575, 1543, 1494, 1459, 1420, 1383, 1311, 1251, 1196, 1152, 1072, 935, 884, 810, 789, $760 \mathrm{~cm}^{-1}$; Anal. Calcd for $\mathrm{C}_{34} \mathrm{H}_{20} \mathrm{~N}_{2} \mathrm{NiO}_{4}$ : C, 70.50; H, 3.48; N, 4.84\%. Found: C, 70.37; H, 3.34; N, 5.01\%.

5e; Yellow powder, yield 39\%; m.p. $>360^{\circ} \mathrm{C}$; UV $\left(\mathrm{CH}_{3} \mathrm{OH}\right) \lambda$ : 366, 321, 297, 285 nm; FTIR (KBr) v: 1608, 1557, 1534 1489, 1458, 1423, 1333, 1299, 1253, 1209, 1191, 1147, 1087, 1001, 980, 887, 791, 735, $674 \mathrm{~cm}^{-1}$; Anal. Calcd for $\mathrm{C}_{34} \mathrm{H}_{20} \mathrm{~N}_{2} \mathrm{O}_{4} \mathrm{Zn}: \mathrm{C}, 69.70 ; \mathrm{H}, 3.44 ; \mathrm{N}, 4.78 \%$. Found: C, 69.46; H, 3.57; N, 4.92\%.

5f; Yellow powder, yield $46 \%$; m.p. $>360^{\circ} \mathrm{C}$; $\mathrm{UV}\left(\mathrm{CH}_{3} \mathrm{OH}\right) \lambda$ : 350, 337, 257, 241, 219 nm; FTIR (KBr) v: 3401, 1609, 1560, 1539, 1493, 1448, 1409, 1327, 1286, 1246, 1232, 1195, 1143 , 1078, 958, 791, $742 \mathrm{~cm}^{-1}$; Anal. Calcd for $\mathrm{C}_{34} \mathrm{H}_{20} \mathrm{CdN}_{2} \mathrm{O}_{4}$ : C, 64.52; H, 3.18; N, 4.43\%. Found: C, 64.61; H, 3.02; N, 4.24\%.

\section{Metal complexes of 2-(2'-hydroxynaphthyl)benzoxazoles (7a-7f)}

7a; Colourless powder, yield $36 \%$; m.p. $>360^{\circ} \mathrm{C}$; UV $\left(\mathrm{CH}_{3} \mathrm{OH}\right) \lambda$ : 373, 357, 319, 305, 253, 244, 233, 219, 213, 209 nm; FTIR (KBr) v: 3436, 1619, 1539, 1455, 1426, 1383, 1308, 1258, 1208, 1177, 1142, 1007, 985, 893, 822, $739 \mathrm{~cm}^{-1}$; Anal. Calcd for $\mathrm{C}_{34} \mathrm{H}_{20} \mathrm{MgN}_{2} \mathrm{O}_{4}$ : C, 74.95; H, 3.70; N, 5.14\%. Found: C, 74.83; H, 3.59; N, 5.30\%. 
7b; Green powder, yield 37\%; m.p. $>360^{\circ} \mathrm{C}$; $\mathrm{UV}\left(\mathrm{CH}_{3} \mathrm{OH}\right) \lambda: 356,319,305,254,217 \mathrm{~nm}$; FTIR (KBr) v: 3431, 1597, 1515, 1448, 1421, 1383, 1259, 1207, 1175, 1143, 1022, 989, 893, 828, 753 $\mathrm{cm}^{-1}$; Mass calcd. for $\mathrm{C}_{34} \mathrm{H}_{20} \mathrm{FeN}_{2} \mathrm{O}_{4}$ 576.0768. Found 576.5782 (100); Anal. Calcd for $\mathrm{C}_{34} \mathrm{H}_{20} \mathrm{FeN}_{2} \mathrm{O}_{4}$ : C, 70.85; H, 3.50; N, 4.86\%. Found: C, 70.65; H, 3.37; N, 4.91\%.

7c; Yellow-green colour powder, yield 30\%; m.p. $>360^{\circ} \mathrm{C}$; $\mathrm{UV}\left(\mathrm{CH}_{3} \mathrm{OH}\right) \lambda$ : 357, 319, 254, 204 nm; FTIR (KBr) v: 3404, 1618, 1538, 1453, 1424, 1380, 1343, 1308, 1257, 1208, 1178, 1142 , 1008, 985, 892, 820, $737 \mathrm{~cm}^{-1}$; Mass calcd. for $\mathrm{C}_{34} \mathrm{H}_{20} \mathrm{CoN}_{2} \mathrm{O}_{4}$ 579.0755. Found 579.5481 (100); Anal. Calcd for $\mathrm{C}_{34} \mathrm{H}_{20} \mathrm{CoN}_{2} \mathrm{O}_{4}: \mathrm{C}, 70.47 ; \mathrm{H}, 3.48 ; \mathrm{N}, 4.83 \%$. Found: C, 70.60; H, 3.29; N, $4.65 \%$.

7d; Yellow powder, yield 32\%; m.p. $>360^{\circ} \mathrm{C}$; $\mathrm{UV}\left(\mathrm{CH}_{3} \mathrm{OH}\right) \lambda: 373,357,319,305,253,245$, 225, 202 nm; FTIR (KBr) v: 1618, 1537, 1452, 1424, 1377, 1342, 1309, 1257, 1208, 1179, 1143, $1010,985,893,820,737 \mathrm{~cm}^{-1}$; Mass calcd. for $\mathrm{C}_{34} \mathrm{H}_{20} \mathrm{~N}_{2} \mathrm{NiO}_{4} 578.0771$. Found 576.6033 (100); Anal. Calcd for $\mathrm{C}_{34} \mathrm{H}_{20} \mathrm{~N}_{2} \mathrm{NiO}_{4}$ : C, 70.50; H, 3.48; N, 4.84\%. Found: C, 70.29; H, 3.34; N, $4.61 \%$.

7e; Yellow powder, yield 38\%; m.p. $>360^{\circ} \mathrm{C}$; $\mathrm{UV}\left(\mathrm{CH}_{3} \mathrm{OH}\right) \lambda$ : 403, 317, $261 \mathrm{~nm}$; FTIR (KBr) v: $1617,1536,1453,1425,1379,1343,1307,1256,1208,1177,1143,1010,985,892,821,736$, $651 \mathrm{~cm}^{-1}$; Mass calcd. for $\mathrm{C}_{34} \mathrm{H}_{20} \mathrm{~N}_{2} \mathrm{O}_{4} \mathrm{Zn}$ 584.0715. Found 584.4229 (100); Anal. Calcd for $\mathrm{C}_{34} \mathrm{H}_{20} \mathrm{~N}_{2} \mathrm{O}_{4} \mathrm{Zn}$ : C, 69.70; H, 3.44; N, 4.78\%. Found: C, 69.56; H, 3.57; N, 4.92\%.

7f; Yellow powder, yield 43\%; m.p. $>360^{\circ} \mathrm{C}$; UV $\left(\mathrm{CH}_{3} \mathrm{OH}\right) \lambda$ : 400, 319, $261 \mathrm{~nm}$; FTIR (KBr) v: 3406, 1618, 1536, 1452, 1422, 1376, 1342, 1305, 1255, 1207, 1174, 1141, 1006, 983, 892, 820, $736 \mathrm{~cm}^{-1}$; Mass calcd. for $\mathrm{C}_{34} \mathrm{H}_{20} \mathrm{CdN}_{2} \mathrm{O}_{4}$ 634.0466. Found 634.4252 (100); Anal. Calcd for $\mathrm{C}_{34} \mathrm{H}_{20} \mathrm{CdN}_{2} \mathrm{O}_{4}$ : C, 64.52; H, 3.18; N, 4.43\%. Found: C, 64.61; H, 3.39; N, 4.24\%.

\section{Biological studies}

The in vitro antibacterial and antifungal activity of 2-(1'/2'-hydroxynaphthyl)benzoxazoles (4 and 6) and their metal complexes (5a-5f and 7a-7f) were carried out against Bacillus subtilis, Escherichia coli, Staphylococcus aureus Aspergillus ficuum, Aspergillus parasiticus, Candida albicans and Aspergillus niger using serial dilution technique in double strength nutrient brothI.P. and Sabouraud dextrose broth-I.P. as a medium The ligands and metal complexes were dissolved in DMSO to give a concentration of $100 \mu \mathrm{g} / \mathrm{ml}$ (stock solution).

Antibacterial assay

A $24 \mathrm{~h}$ fresh cultures were obtained by inoculation of respective bacteria in double strength nutrient broth-I.P. followed by incubation at $37 \pm 1^{\circ} \mathrm{C}$. The stock solution of ligands (4 and 6$)$ and their metal complexes (5a-5f and 7a-7f) was serially diluted in tube containing $1 \mathrm{ml}$ of sterile double strength nutrient broth-I.P. to get a concentration of 100 to $3.12 \mu \mathrm{g} / \mathrm{ml}$ and then inoculated with $100 \mu \mathrm{l}$ of suspension of respective organisms in sterile saline (B. subtilis, E. coli and $S$. aureus). The inoculated tubes were incubated at $37 \pm 1^{\circ} \mathrm{C}$ for $24 \mathrm{~h}$ and minimum inhibitory concentrations (MIC) were determined. From the observed MIC values, the exact MIC values were determined by making suitable dilution of stock solution. 


\section{Antifungal assay}

The antifungal activity of 4, 5a-5f, 6 and 7a-7f against the fungal species A. ficcum, $A$. parasiticus, $C$. albicans and $A$. niger was determined by serial dilution method similar to Antibacterial assay using Sabouraud dextrose broth-I.P. following the incubation condition of $25 \pm 1^{\circ} \mathrm{C}$ for a period of 7 days, except $C$. albicans $\left(37 \pm 1^{\circ} \mathrm{C}\right.$ for a period of $\left.36 \mathrm{~h}\right)$.

\section{Acknowledgements}

The authors are thankful to UGC, New Delhi for financial support and Dr. B. Narasimhan, Department of Pharmaceutical Sciences, G J University of Science \& Technology, Hisar for helpful discussions. We also thank Prof. S. P. Singh, Department of Chemistry, Kurukshetra University, Kurukshetra and Mass Spectrometric facility, University of California, San Francisco for providing mass spectral data.

\section{References}

1. Henary, M. M.; Fahrni, C. J. J. Phys. Chem. A 2002, 106, 5210.

2. Jang, Y.-K.; Kim, D.-E.; Kim, W.-S.; Kwon, O.-K.; Lee, B.-J.; Kwon, Y.-S. Colloids and Surfaces: Physicochem. Eng. Aspects 2006, 284, 331.

3. (a) Rodembusch, F. S.; Brand, F. R.; Correa, D. S.; Pocos, J. C.; Martinelli, M.; Stefani, V. Mat. Chem. Phys. 2005, 92, 389. (b) Rodembusch, F. S.; Leusin, F. P.; Medina L. F.; Brandelli, A.; Stefani, V. Photochem. Photobiol. Sc. 2005, 4, 254.

4. Pla-Dalmau, A. J. Org. Chem. 1995, 60, 5468.

5. (a) Sakio, S.; Miyaoka, S.; Kaneko, S.; Fujii, T.; Takai, T. Japananese Patent 2,001,125,292, 2001. (b) Shi, S. Q. Taiwan Patent 401,453, 2000. (c) Nakamura, N.; Miyairi, K. European Patent 0,801,518, 1997.

6. Ogawa, A. K.; Abou-Zied, O. K.; Tsui, V.; Jimenez, R.; Case, R. A.; Romesberg, F. E. J. Am. Chem. Soc. 2000, 122, 9917.

7. (a) Hoveyda, H. R.; Rettig, S. J.; Orwig, C. Inorg. Chem. 1993, 32, 4909. (b) Tanaka, K.; Kumagai, T.; Aoki, H.; Deguchi, M.; Iwata, S. J. Org. Chem. 2001, 66, 7328.

8. Kumar, D.; Jacob, M. R.; Reynold, M. B.; Kerwin, S. M. Bioorg. Med. Chem. 2002, 10, 3997.

9. Reyzer, M. L.; Brodbelt, J. S.; Kerwin, S. M.; Kumar, D. Nucleic Acid Res. 2001, e103.

10. Pharmacopoeia of India; Ministry of Health Department: Govt. of India: New Delhi, 1996; Vol. 2, pp A-88.

11. Cappucino, J. G.; Sherman, N. Microbiology-A Laboratory Manual; Addison Wesley: California, 1999; pp 263-265.

12. Varma, R. S.; Saini, R. K.; Prakash, O. Tetrahedron Lett. 1997, 38, 2621.

13. Campo, L. F.; Correa, D. S.; Araujo, M. A.; Stefani, V. Macromol. Rapid Commun. 2000, 21, 832. 